\title{
Reduction of energy requirements of steers fed on low-quality- roughage diets using trenbolone acetate
}

\author{
By R. A. HUNTER AND J. E. VERCOE \\ CSIRO, Division of Tropical Animal Science, Tropical Cattle Research Centre, \\ North Rockhampton, Queensland 4702, Australia
}

(Received 17 February 1987 - Accepted 8 June 1987)

\begin{abstract}
1. Six steers implanted with $300 \mathrm{mg}$ trenbolone acetate and six steers not implanted were fed on low protein, low-quality-roughage diets ad lib. in two experiments. The steers were Hereford (Bos taurus) $\times$ Brahman (Bos indicus) crossbreds (50:50), initially of about $400 \mathrm{~kg}$ mean live weight (LW). In the first experiment of 8 weeks duration roughage was given alone. In the second experiment of 6 weeks duration the diet was supplemented with $100 \mathrm{~g}$ urea and $4.6 \mathrm{~g}$ sulphur daily. The same steers were implanted in each experiment. At the conclusion of each experiment metabolic rate was measured after a $72 \mathrm{~h}$ fast.

2. In the first experiment control and implanted steers had similar rates of $\mathrm{LW}$ loss $(0.57$ and $0.59 \mathrm{~kg} / \mathrm{d}$ respectively). Implanted steers had significantly $(P<0.01)$ lower feed intakes $(12.8 v .10 .9 \mathrm{~g}$ dry matter $(\mathrm{DM}) / \mathrm{kg}$ LW), significantly $(P<0.01)$ lower fasting metabolic rates even after adjustment for intake $(83.3 \nu .74 .5 \mathrm{~kJ} / \mathrm{kg} \mathrm{per}$ d) and significantly $(P<0.01)$ lower plasma insulin concentrations $(24 v .19 \mu \mathrm{units} / \mathrm{ml})$. Differences in plasma concentrations of free 3,5,3'-triiodothyronine $\left(T_{3}\right)$, non-esterified fatty acids and urea-nitrogen were not significant.

3. In the second experiment intake of the supplemented diet was similar in both control and trenbolone acetatetreated steers $(19.5$ and $20.0 \mathrm{~g} \mathrm{DM} / \mathrm{kg} \mathrm{LW}$ respectively). LW gains were 0.23 and $0.41 \mathrm{~kg} / \mathrm{d}$ for control and implanted steers respectively, the difference being significant $(P<0.05)$. Fasting metabolic rate $(76.9 v$. $70.7 \mathrm{~kJ} / \mathrm{kg}$ per d) was significantly $(P<0.05)$ lower in implanted steers.
\end{abstract}

In seasonally dry areas of the world grazing cattle lose weight for a period each year when the intake of low-quality pasture does not provide sufficient digestible energy to meet the animals' maintenance energy requirements. One strategy, using small inputs, to reduce the rate of live-weight loss is to stimulate feed intake by providing deficient nutrients, usually protein, as supplements. Another is to reduce maintenance energy requirements by manipulating metabolic processes. Since the energy cost of protein turnover is a substantial component of maintenance energy requirements, some estimates varying between 25 and $50 \%$ (Edmunds et al. 1980; Webster et al. 1980), a reduction in protein turnover should be consistent with a decrease in energy requirements for maintenance. Trenbolone acetate has been shown to reduce the rate of protein synthesis and presumably the rate of protein degradation in female rats and female lambs gaining weight (Vernon \& Buttery, 1976, $1978 a, b$; Sinnett-Smith et al. 1983). It is therefore potentially suitable for reducing energy requirements in undernourished animals losing weight.

The present paper reports experiments designed to study the effect of trenbolone acetate on feed intake, metabolic rate and rate of live-weight change in steers fed on poor-qualityroughage diets. Of particular interest was the effect on feed intake, as treatment with trenbolone acetate has been found to reduce plasma urea concentrations (Galbraith, 1980). In cattle fed on low-nitrogen diets, urea recycled to the rumen is an important source of ammonia for rumen microbes. Low plasma urea and low rumen $\mathrm{NH}_{3}$ concentrations have been shown to be associated with reduced rumen digestion rates and reduced feed intakes in cattle fed on low-N-roughage diets (Hunter \& Siebert, 1985a,b). 
MATERIALS AND METHODS

Expt 1. The effect of trenbolone acetate on steers losing weight on a roughage diet Animals, diet and sampling procedures. Twelve Brahman (Bos indicus) $\times$ Hereford (Bos taurus) (50:50) steers, approximately 2 years of age and $400 \mathrm{~kg}$ mean live weight, were fed on long-chopped mature pasture grass (Bothriochloa insculpta) hay ad lib. The steers were housed in individual pens in a roofed animal house and kept free of internal and external parasites. For the month before the commencement of the experiment they had been fed on lucerne (Medicago sativa) hay ad lib. They were divided into two groups of six animals per group. Animals in one group were implanted subcutaneously on the upper surface of the ear with $300 \mathrm{mg}$ trenbolone acetate (Hoechst Australia Ltd, Melbourne) at the commencement of the experiment and again after $40 \mathrm{~d}$. Animals in the other group served as controls. The amount of feed offered was arranged so that the daily feed refusal was between 1.0 and $1.5 \mathrm{~kg}$. The experimental diet was given for 1 week before the commencement of the experiment. Steers were weighed each week $24 \mathrm{~h}$ after feeding. A sample of venous blood was collected into heparinized tubes each week at the time of weighing. Plasma was obtained by centrifugation and stored at $-15^{\circ}$. Feed intake and liveweight change were recorded for 8 weeks. During the 4 th week a sample of rumen fluid, $24 \mathrm{~h}$ after feeding, was obtained using a stomach tube, strained through Terylene gauze, acidified with hydrochloric acid and stored at $-15^{\circ}$ for analysis of $\mathrm{NH}_{3}$ concentration.

Measurement of fasting metabolic rate. At the conclusion of the 8-week feeding period steers were fasted for $72 \mathrm{~h}$ before measurement of metabolic rate. As measurements could be made on only one implanted and one control steer each day, feeding of the experimental diet continued until the beginning of the fast of each animal. Measurements were made in confinement-type respiration chambers similar to those described by Turner \& Thornton (1966). The chambers were run at a dry-bulb temperature of about $29^{\circ}$ (approximately thermoneutral for fasted, tropically adapted cattle) and at about $40 \%$ relative humidity. The rates of oxygen consumption and carbon dioxide production were estimated as the regression of the volumes of $\mathrm{O}_{2}$ and $\mathrm{CO}_{2}$ over time, each chamber being sampled every $6 \mathrm{~min}$. At least three consecutive runs were made per animal, each lasting about $90 \mathrm{~min}$. The mean of the last three runs for each day was taken as the value for that animal. Heat production was calculated from the gas exchange using the values of Brouwer (1965).

Measurement of body solids. Total body solids were determined after $48 \mathrm{~h}$ of the fast before measurement of metabolic rate. Steers were fasted with free access to water for $32 \mathrm{~h}$ and injected intravenously with $3 \mathrm{mCi}$ sterile tritiated water diluted with sterile saline $(9 \mathrm{~g}$ sodium chloride/1). The animals were then denied access to water and a sample of blood from the jugular vein collected after a further $16 \mathrm{~h}$. Steers were weighed at this time. Plasma was lyophilized and water of sublimation subjected to liquid-scintillation counting for analysis of tritium concentration. Total body water was calculated by dilution of the dose using the formula of Little \& Morris (1972). This value, subtracted from live weight, was considered to be body solids.

\section{Expt 2. The effect of trenbolone acetate on steers fed on low- $N$ roughage supplemented with urea and sulphur}

At the conclusion of Expt 1, all pellets of the implants that could be found were removed surgically and all twelve Brahman crossbred steers allowed to graze a pasture of mixed tropical grasses for approximately 1 month. They were then returned to the animal house, treated to eliminate gastrointestinal helminths, and fed on a pre-experimental diet of longchopped pasture hay ad lib. for a further 3 weeks. During the period between experiments there was a small live-weight gain. There was no significant difference in intake of the pre- 
experimental diet between groups (23.0 (SE 0.54) v. 23.2 (SE 0.56) g dry matter (DM)/kg live weight).

The twelve steers were divided into the same two groups as in Expt 1 and the same six steers implanted in the ear with $300 \mathrm{mg}$ trenbolone acetate. The same animals were used as the treated group in case all pellets of trenbolone acetate had not been removed at the end of the first experiment. The other six steers served as controls. The experimental diet, a long-chopped mixture of Dicanthium aristatum and Bothriochloa insculpta $(60: 40, \mathrm{w} / \mathrm{w})$ supplemented daily with $100 \mathrm{~g}$ urea and $4.6 \mathrm{~g}$ sulphur as diluted $\mathrm{H}_{2} \mathrm{SO}_{4}$, was fed ad lib. for $5 \mathrm{~d}$ before the commencement of the experiment at implantation. A solution containing the urea and $S$ was mixed with the feed. Measurements of live weight and feed intake were made for 6 weeks before measurement of fasting metabolism. A sample of venous blood was collected at intervals of 2 weeks, $24 \mathrm{~h}$ after feeding. Samples of rumen fluid at 6 and $24 \mathrm{~h}$ after feeding were collected by stomach tube in the 4 th week. All husbandry, sampling and measurement procedures were the same as for Expt 1.

\section{Chemical analysis}

DM was determined after oven drying at $80^{\circ}$ to constant weight. $\mathrm{N}$ concentration, after a Kjeldahl digestion, and $\mathrm{NH}_{3}$ concentration in acidified rumen fluid were determined using an AutoAnalyzer (Technicon Instruments Corp., New York) by the method of Williams \& Twine (1967). Urea-N concentration in plasma was determined using the AutoAnalyzer by the Technicon Instruments Corp. (1972) modification of the method of Marsh et al. (1965). Cell-wall constituents were determined by the method of Van Soest \& Wine (1967). Insulin was determined using a radioimmunoassay kit (Corning Medical and Scientific, Medfield, USA) except that five standard concentrations of bovine insulin no. 1-5500 (Sigma Chemical Co, St Louis, USA) were substituted for the seven standard concentrations of human insulin supplied with the kit. Free 3,5,3'-triiodothyronine $\left(\mathrm{T}_{3}\right)$ was determined by radioimmunoassay (Amersham International Plc, Amersham, Bucks). The concentration of non-esterified fatty acids in plasma was determined by the method of Dole (1956) using the modification of Tarrant et al. (1962). Albumin concentration in plasma was determined using the AutoAnalyzer by the method described by Technicon Instruments Corp. (1974).

\section{Statistical analysis}

The significance of difference between treatment groups was determined by analysis of variance. With indices which were measured at intervals throughout the experiments the analysis had treatment and time as independent variables and variance was therefore partitioned into treatment, time, animals-within-treatment and time, the interaction of treatment and time and residual (animal-within-treatment $\times$ times). Treatment effects were tested against animal-within-treatment and other effects against residual.

The rate of live-weight change was derived from the regression of live weight $v$. time. Regression coefficients were calculated for each steer and then these coefficients were analysed by analysis of variance.

\section{RESULTS}

\section{Expt 1. The effect of trenbolone acetate on steers losing weight on a roughage diet} The chemical composition of the diet (g/ $\mathrm{kg} \mathrm{DM}$ ) was organic matter $899, \mathrm{~N} \mathrm{4} 3$, cell-wall constituents 751 .

The mean rate of live-weight loss was approximately $0.6 \mathrm{~kg} / \mathrm{d}$ for both implanted and control steers (Table 1). Feed intake over the 8 -week period was significantly $(P<0 \cdot 01)$ lower in the implanted steers. Consequently there was an advantage in feed conversion 
Table 1. Expt 1. Effect of trenbolone acetate on mean growth rate, feed intake and some metabolic characteristics of steers

\begin{tabular}{|c|c|c|c|c|}
\hline & $\begin{array}{c}\text { Control } \\
(n 6)\end{array}$ & $\begin{array}{l}\text { Trenbolone } \\
\text { acetate } \\
(n 6)\end{array}$ & SEM & $\begin{array}{c}\text { Statistical } \\
\text { significance } \\
\text { of comparisons }\end{array}$ \\
\hline Live wt at beginning of experiment $(\mathrm{kg})$ & 400 & $40 \mathrm{l}$ & $11 \cdot 2$ & NS \\
\hline Live wt change $(\mathrm{kg} / \mathrm{d})$ & -0.57 & -0.59 & 0.083 & NS \\
\hline Body solids at end of experiment $(\mathrm{kg})$ & 104 & 116 & 6.8 & NS \\
\hline Feed intake (g DM $/ \mathrm{kg}$ live $w t)$ & $12 \cdot 8$ & $10 \cdot 9$ & 0.43 & ** \\
\hline $\begin{array}{l}\text { Feed conversion efficiency } \\
\text { (kg DM feed } / \mathrm{kg} \text { wt gain) }\end{array}$ & $-11 \cdot 1$ & $-7 \cdot 2$ & 2.09 & NS \\
\hline Fasting metabolism $(\mathrm{MJ} / \mathrm{d})$ & $28.4 \dagger$ & $25 \cdot 5 \dagger$ & 0.41 & ** \\
\hline Fasting metabolic rate $(\mathrm{kJ} / \mathrm{kg}$ per $\mathrm{d})$ & $83 \cdot 3 \dagger$ & $74.5 \dagger$ & $1 \cdot 30$ & ** \\
\hline Plasma insulin ( $\mu$ units $/ \mathrm{ml})$ & 24 & 19 & $1 \cdot 1$ & ** \\
\hline Plasma free $T_{3}(\mathrm{pg} / \mathrm{ml})$ & 1.4 & $1 \cdot 1$ & $0 \cdot 13$ & NS \\
\hline Plasma non-esterified fatty acids $(\mu \mathrm{mol} / 1)$ & 1382 & 1135 & 169 & NS \\
\hline Plasma albumin $(\mathrm{g} / \mathrm{l})$ & $41 \cdot 2$ & $38 \cdot 8$ & 0.79 & NS \\
\hline Plasma urea-nitrogen $(\mathrm{mg} / \mathrm{l})$ & 24 & 18 & $3 \cdot 1$ & NS \\
\hline Rumen ammonia $24 \mathrm{~h}$ after feeding $(\mathrm{mg} / \mathrm{l})$ & 24 & 16 & $7 \cdot 1$ & NS \\
\hline
\end{tabular}

DM, dry matter; $\mathrm{T}_{3}, 3,5,3^{\prime}$-triiodothyronine; NS, not significant.

** $P<0.01$.

+ Unadjusted mean.

efficiency in favour of implanted steers, although it was not significant. The treatment $\times$ time interaction was not significant.

Fasting metabolism, whether expressed as total heat production per $\mathrm{d}$ or heat production per unit live weight, was significantly $(P<0 \cdot 01)$ lower in implanted steers. As previous feed intake and live weight affect fasting metabolism, covariance adjustments were made. These showed that treatment differences in total heat production could not be accounted for by differences in either weight or intake. One treated steer which did not adjust to confinement in the respiration chamber and which had an abnormally high heat production was omitted from the analysis of the metabolic rate results. Differences in the weight of body solids between treatments at the end of the experiment were not significant (Table 1).

Concentration of plasma insulin was significantly $(P<0.01)$ lower in implanted steers. The mean concentrations of free $T_{3}$, non-esterified fatty acids and albumin in plasma were not significantly different between treatments. The concentrations of urea- $\mathrm{N}$ in plasma each week are shown in Fig. 1. The treatment difference in concentration was not significant. However there was a significant $(P<0.01)$ treatment $\times$ time interaction. Rumen $\mathrm{NH}_{3}$ concentrations were not significantly different between treatments.

\section{Expt 2. The effect of trenbolone acetate on steers fed on low- $N$ roughage supplemented with urea and $S$}

The chemical composition of the Dicanthium/Bothriochloa mixture (g/ $\mathrm{kg} \mathrm{DM})$ was organic matter $845, \mathrm{~N} \mathrm{3.9}$, cell-wall constituents 761 .

The results of one steer, the same animal omitted from analysis of metabolic rate values in the first experiment, were omitted from all analyses. This steer's growth rate was atypical for his treatment group and again this steer did not adjust to confinement in a respiration chamber. Steers treated with trenbolone acetate had significantly $(P<0.05)$ higher liveweight gains (Table 2). The advantage in feed conversion efficiency in favour of the implanted group failed to reach significance at $P<0.05(P=0.07)$. There was no significant difference between groups in total heat production per $\mathrm{d}$. However, when the 


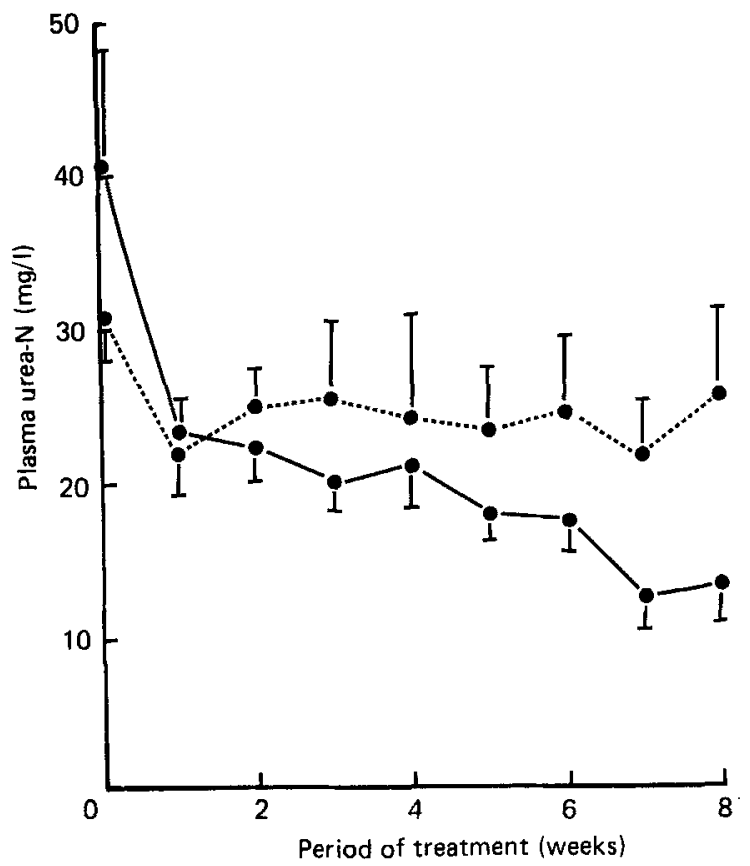

Fig. 1. Expt 1. Plasma urea-nitrogen concentration in control steers (---) and those treated with trenbolone acetate $(-)$ ). Points are means with their standard errors for six animals per group.

Table 2. Expt 2. Effect of trenbolone acetate on mean growth rate, feed intake and some metabolic characteristics of steers supplemented with urea and sulphur

\begin{tabular}{|c|c|c|c|c|}
\hline & $\begin{array}{l}\text { Control } \\
(n 6)\end{array}$ & $\begin{array}{c}\text { Trenbolone } \\
\text { acetate } \\
(n 5)\end{array}$ & SEM & $\begin{array}{c}\text { Statistical } \\
\text { significance } \\
\text { of comparisons }\end{array}$ \\
\hline Live wt at beginning of experiment $(\mathrm{kg})$ & 405 & 412 & $13 \cdot 4$ & NS \\
\hline Live-wt gain $(\mathrm{kg} / \mathrm{d})$ & 0.23 & 0.41 & $0 \cdot 040$ & $*$ \\
\hline Feed intake (g DM/kg live wt) & $19 \cdot 5$ & $20 \cdot 0$ & $0 \cdot 47$ & NS \\
\hline $\begin{array}{l}\text { Feed conversion efficiency } \\
\text { (kg DM feed } / \mathrm{kg} \text { wt gain) }\end{array}$ & $37 \cdot 0$ & $20 \cdot 9$ & $5 \cdot 37$ & NS \\
\hline Fasting metabolism $(\mathrm{MJ} / \mathrm{d})$ & $29 \cdot 1+$ & $27 \cdot 7 \dagger$ & 0.76 & NS \\
\hline Fasting metabolic rate $(\mathrm{kJ} / \mathrm{kg}$ per d) & $76.9 \dagger$ & $70 \cdot 7 \dagger$ & $1 \cdot 16$ & * \\
\hline Plasma insulin ( $\mu$ units $/ \mathrm{ml}$ ) & 28 & 25 & $1 \cdot 1$ & NS \\
\hline Plasma free $T_{3}(p g / m l)$ & $1 \cdot 4$ & $1 \cdot 1$ & $0 \cdot 13$ & NS \\
\hline Plasma urea-nitrogen $(\mathrm{mg} / \mathrm{l})$ & 60 & 52 & $9 \cdot 0$ & NS \\
\hline Plasma albumin $(\mathrm{g} / \mathrm{l})$ & $39 \cdot 2$ & $37 \cdot 7$ & 0.73 & NS \\
\hline Rumen ammonia (mg/l):6 h after feeding & 107 & 85 & 8.7 & NS \\
\hline $24 \mathrm{~h}$ after feeding & 40 & 32 & $5 \cdot 0$ & NS \\
\hline
\end{tabular}

DM, dry matter; $\mathrm{T}_{3}, 3,5,3^{\prime}$-triiodothyronine; NS, not significant.

$* P<0.05$.

$\dagger$ Unadjusted mean.

values were adjusted by covariance analysis for the amount of feed eaten daily before fasting, steers treated with trenbolone acetate had significantly $(P<0.05)$ lower heat productions. Heat production expressed per unit live weight was also significantly $(P<$ $0.05)$ lower in trenbolone acetate-treated steers. After adjustment for the amount of feed eaten, the significance of the difference increased $(P<0.01)$. 
Plasma concentrations of insulin, free $T_{3}$, albumin, urea-N and rumen $\mathrm{NH}_{3}$ concentrations were not significantly different between treatments (Table 2).

\section{DISCUSSION}

The results showed that trenbolone acetate was effective in reducing fasting metabolic rate in adult steers either losing weight or gaining weight slowly. It is possible that part of the energy-saving effect of trenbolone acetate was mediated via a reduction in the rate of protein breakdown and of protein synthesis in muscle. Treatment with trenbolone acetate has been shown to reduce the rate of protein synthesis and presumably that of protein degradation in female rats and female lambs (Vernon \& Buttery, 1976, 1978 $a, b$; SinnettSmith et al. 1983). It may be calculated that about two-fifths of the $10 \%$ reduction observed in $\mathrm{O}_{2}$ consumption could be ascribed to skeletal muscle, assuming that (1) $30 \%$ of $\mathrm{O}_{2}$ consumption in the whole body is by skeletal muscle (Oddy, 1986), (2) one-third of muscle $\mathrm{O}_{2}$ consumption is related to protein turnover (Oddy et al. 1984), (3) energy cost of protein degradation is $15 \%$ of that of protein synthesis (Oddy, 1986), (4) trenbolone acetate decreased protein synthesis in skeletal muscle by $33 \%$ (Sinnett-Smith et al. 1983).

Even though the assumptions made in these calculations are substantial, it is unlikely that the measured reduction of $10 \%$ in metabolic rate could be accounted for entirely by the effect of trenbolone acetate on protein turnover in skeletal muscle.

The resultant depression in metabolic rate of the steers appears to be consistent with the results of Galbraith \& Geraghty (1982) and Stafford et al. (1981) who found that when compared with controls, steers implanted with a combination of trenbolone acetate and an oestrogen lost less weight on a restricted concentrate and roughage mixture, or gained more weight on a diet estimated to meet maintenance requirements. These authors concluded that the implanted steers required less metabolizable energy to maintain live weight than control steers. However these experiments cannot be compared directly with the present one because trenbolone acetate in combination with an oestrogen was used. It is not known whether the metabolic effects of trenbolone and oestrogen-like compounds are dependent or independent when in combination. Lobley et al. (1985) found that a combined implant of trenbolone acetate and oestradiol- $17 \beta$ had no significant effect on metabolic rate of growing steers.

Depression in voluntary feed intake of the unsupplemented diet in trenbolone acetatetreated steers could possibly have been related to reduced energy demand by treated steers. However, the capacity of the tissues to use nutrients would have far exceeded amounts supplied by this diet. More probably the reduced feed intake was related to the lower rumen $\mathrm{NH}_{3}$ concentrations in implanted steers, even though the observed differences in concentrations were not significant at $P<0.05$. A sample of rumen fluid, obtained from only one site by passing a stomach tube, may not be representative of the whole rumen, nor may results obtained $24 \mathrm{~h}$ after feeding necessarily indicate events in the fed animal. The results tend to confirm this as a surprisingly wide range of concentrations of $\mathrm{NH}_{3}$ was obtained; control 5-54 mg/l, trenbolone acetate-treated 3-33 mg/l. Reduced recycling of urea to the rumen should be consistent with a reduction in protein turnover. Donaldson \& Heitzman (1982) showed that in cattle implanted with trenbolone acetate there was reduced urea synthesis and reduced plasma urea concentrations compared with controls. A positive relation between plasma urea concentration and rumen $\mathrm{NH}_{3}$ concentration in cattle fed on low-N-roughage diets has been demonstrated (Vercoe, 1969; Hunter \& Siebert, 1985b). Supportive evidence for the proposed effect of endogenous $\mathrm{N}$ supply to the rumen on feed intake is that intakes of the diet, supplemented with urea and S, were similar in trenbolone acetate-treated and control steers. 
The large increase in weight gain of almost $1 \mathrm{~kg} / \mathrm{d}$ between experiments could not be accounted for by the increase in intake of approximately $3.5 \mathrm{~kg} / \mathrm{d}$ after supplementation with urea and $\mathrm{S}$. It is likely that the measured weight gain in Expt 2 was confounded with increases in rumen load. Over the 6-week experimental period, steers in both treatment groups steadily increased intake, calculated on a weekly basis, from 18.5 to $21.0 \mathrm{~g} / \mathrm{kg}$ live weight. There was no corresponding increase in intake with time in Expt 1. There are reports in the literature which show that ruminants sometimes take a number of weeks to adapt fully to a new roughage diet (e.g. Amaning-Kwarteng et al. 1982).

In conclusion, although the results suggest that trenbolone acetate was effective in reducing maintenance energy requirements of undernourished adult cattle, the mechanisms by which this was achieved are not clear. Despite the difficulties of interpretation of some of the results, they are consistent with the hypothesis that at least part of the energy-saving role of trenbolone acetate was associated with its effect on reducing protein turnover.

The authors thank Mr C. R. Holmes, Mrs C. G. Johnson, Mr T. Magner and Mr W. D. Sim for technical assistance. The study was partly financed by the Australian Meat and Livestock Research and Development Corporation. Hoechst Australia Ltd kindly donated the trenbolone acetate.

\section{REFERENCES}

Amaning-Kwarteng, K., Kellaway, R. C. \& Leibholz, J. (1982). Proceedings of the Nutrition Society of Australia $7,176$.

Brouwer, E. (1965). In Energy Metabolism, Publication of the European Association of Anima! Production no. 11, pp. 441-443 [K. L. Blaxter, editor]. London: Academic Press.

Dole, V. P. (1956). Journal of Clinical Investigation 35, $150 \cdots 154$

Donaldson, I. A. \& Heitzman, R. J. (1982). Proceedings of the Nutrition Society 42, 59A.

Edmunds, B. M., Buttery, P. J. \& Fisher, C. (1980). In Energy Metabolism, pp. 129-133 [L. E. Mount, editor]. London: Butterworths

Galbraith, H. (1980). Veterinary Record 107, 559-560.

Galbraith, H. \& Geraghty, K. J. (1982). Animal Production 35, 277-280.

Hunter, R. A. \& Siebert, B. D. (1985a). British Journal of Nutrition 53, 637-648.

Hunter, R. A. \& Siebert, B. D. (1985b). British Journal of Nutrition 53, 649-656.

Little, D. A. \& Morris, J. G. (1972). Journal of Agricultural Science, Cambridge 78, 505-508.

Lobley, G. E., Connell, A., Mollison, G. S., Brewer, A., Harris, C. I., Buchan, V. \& Galbraith, H. (1985). British Journal of Nutrition 54, 681-694.

Marsh, W. H., Fingerhut, B. \& Miller, H. (1965). Clinical Chemistry 11, 624-627.

Oddy, V. H. (1986). Muscle protein metabolism. PhD Thesis, Cambridge University.

Oddy, V. H., Gooden, J. M. \& Annison, E. F. (1984). Australian Journal of Biological Sciences 37, 375-388.

Sinnett-Smith, P. A., Dumelow, N. W. \& Buttery, P. J. (1983). British Journal of Nutrition 50, $225-234$.

Stafford, S. J., Galbraith, H. \& Topps, J. H. (1981). Animal Production 32, 378-379.

Tarrant, M. E., Thompson, R. H. S. \& Wright, P. H. (1962). Biochemical Journal 84, 6-10.

Technicon Instruments Corp. (1972). Clinical Method no. 01. New York: Technicon Instruments Corp.

Technicon Instruments Corp. (1974), Technicon Method no. SE4-0030FD4. New York: Technicon Instruments Corp.

Turner, H. G. \& Thornton, R. F. (1966). Proceedings of the Australian Society of Animal Production 6, 413-419.

Van Soest, P. J. \& Wine, R. H. (1967). Journal of the Association of Official Agricultural Chemists 50, 50-55.

Vercoe, J. E. (1969). Australian Journal of Agricultural Research 20, 191-197.

Vernon, B. G. \& Buttery, P. J. (1976). British Journal of Nutrition 36, 575-579.

Vernon, B. G. \& Buttery, P. J. (1978a) British Journal of Nutrition 40, 563-572.

Vernon, B. G. \& Buttery, P. J. (1978b). Animal Production 26, 1-9.

Webster, A. J. F., Lobley, G. E., Reeds, P. J. \& Pullar, J. D. (1980). In Energy Metabolism, pp. 125-128 [L. E. Mount, editor]. London: Butterworths.

Williams, C. H. \& Twine, J. R. (1967). CSIRO Division of Plant Industry Technical Paper no. 24. Canberra : CSIRO Division of Plant Industry. 